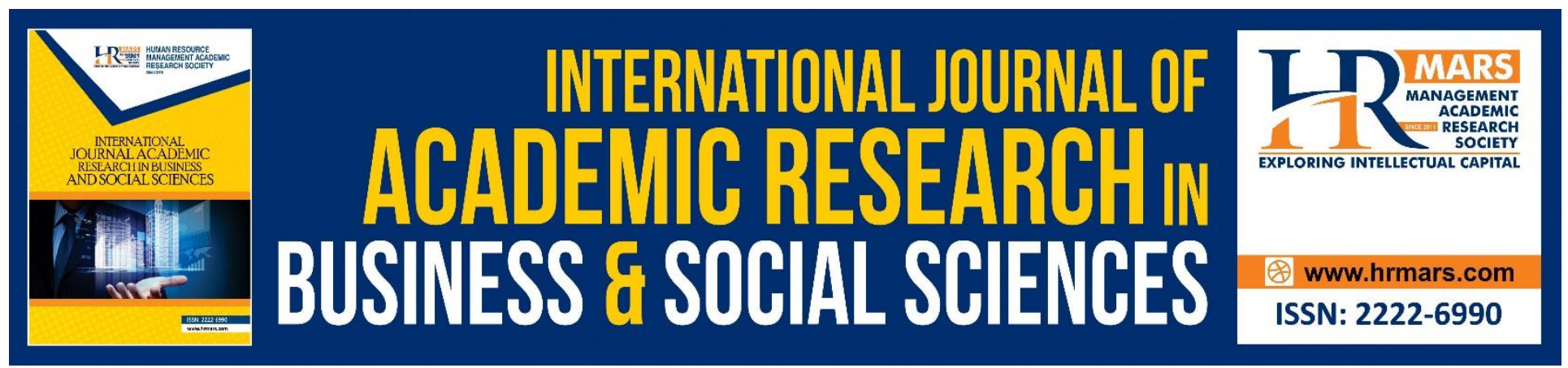

\title{
Impact of Electricity Crisis on Industrial Growth in Pakistan: A Multiple Regression Analysis Approach
}

Ikramuddin Junejo, Jawad Raza Khoso

To Link this Article: http://dx.doi.org/10.6007/IJARBSS/v8-i9/4659

DOI: $\quad 10.6007 /$ IJARBSS/v8-i9/4659

Received: 11 August 2018, Revised: 05 Sept 2018, Accepted: 29 Sept 2018

Published Online: 15 October 2018

In-Text Citation: (Junejo \& Khoso, 2018)

To Cite this Article: Junejo, I., \& Khoso, J. R. (2018). Impact of Electricity Crisis on Industrial Growth in Pakistan: A Multiple Regression Analysis Approach. International Journal of Academic Research in Business and Social Sciences, 8(9), 851-862.

\section{Copyright: (C) 2018 The Author(s)}

Published by Human Resource Management Academic Research Society (www.hrmars.com)

This article is published under the Creative Commons Attribution (CC BY 4.0) license. Anyone may reproduce, distribute, translate and create derivative works of this article (for both commercial and non-commercial purposes), subject to full attribution to the original publication and authors. The full terms of this license may be seen

at: $\underline{\text { http://creativecommons.org/licences/by/4.0/legalcode }}$

Vol. 8, No. 9, September 2018, Pg. 851 - 862

Full Terms \& Conditions of access and use can be found at http://hrmars.com/index.php/pages/detail/publication-ethics 


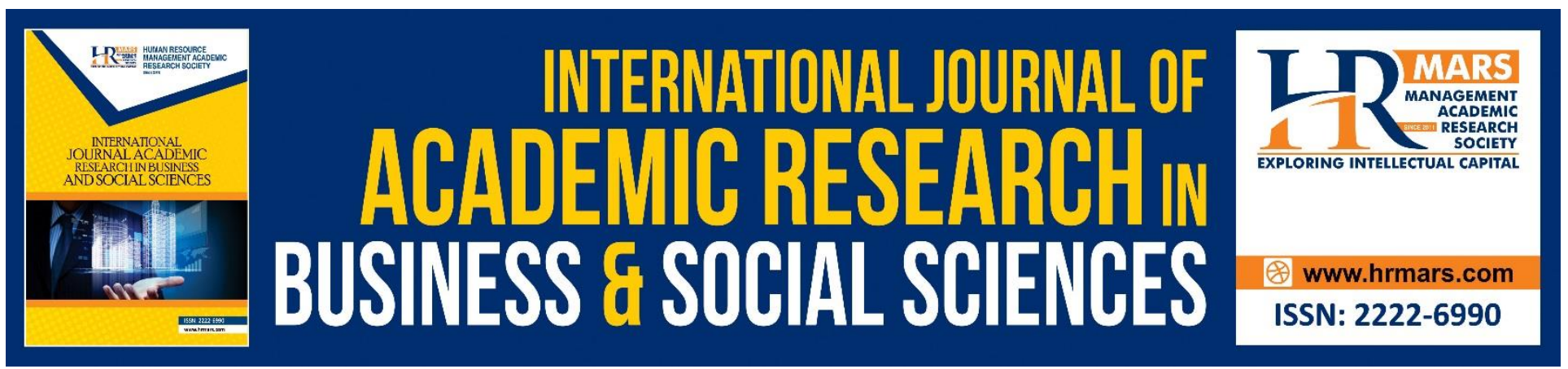

\title{
Impact of Electricity Crisis on Industrial Growth in Pakistan: A Multiple Regression Analysis Approach
}

\author{
Ikramuddin Junejo \\ Lecturer, Department of Management Sciences, SZABIST Hyderabad campus, Sindh, Pakistan \\ Jawad Raza Khoso \\ Assistant Professor/ HOC, Head of Campus, SZABIST Hyderabad campus, Sindh, Pakistan
}

\begin{abstract}
Purpose- This study examines the impact of electricity crisis on industrial growth in Pakistan. It is second largest sector of economy in terms of GDP contribution but due to electricity crisis in Pakistan industrial growth has decreased from $4.5 \%$ to $3.6 \%$ in 2015 . The overall electricity demand is growing in Pakistan since 2000. NEPRA (2016) indicates that annual growth of electricity consumption also reduced from $3.31 \%$ to $0.24 \%$ in 2015 .

Design/methodology/approach- Time series data from 2005-2015 has been used for analysis. Data is collected from various sources that include Asian Development Bank and National Electric Power Regulatory Authority (NEPRA). Industrial growth output percentage, industrial annual growth rate of electricity consumption percentage, industrial consumer percentage, industrial electricity consumption percentage and Industrial electricity consumption Gwh variables are taken for analysis. Data will be analyzed through statistical technique multiple regression analysis in SPSS version 17.

Findings- Based on results, all studied variables are found to have significant and positive impact on industrial growth output percentage.

Originality/value- In previous studies research scholars investigated overall energy crisis impact on GDP of any economy. This study gives insight into industrial sector of Pakistan and this study can be extended to other less developed countries which are also facing electricity crisis in their respective countries.
\end{abstract}

Keywords: Industrial Growth, Multiple Regressions, Electricity Consumption

\section{Introduction}

\section{Electricity Crisis in Pakistan}

The industrial growth has positive and significant impact on overall GDP (Gross domestic product), many countries including, Taiwan, China and Korea are the best examples of positive relationship between industrial growth and GDP. Industrial sector has also studied impact on export and import with respect to balance of payment. According to World Bank (2005) electricity serves as an 
INTERNATIONAL JOURNAL OF ACADEMIC RESEARCH IN BUSINESS AND SOCIAL SCIENCES Vol. 8, No. 9, Sept. 2018, E-ISSN: 2222-6990 @ 2018 HRMARS

important input for industrial sector especially for developing countries like Pakistan. In Pakistan electricity is mainly supplied through two organizations, Karachi Electricity Supply Corporation (KESC) and Water and Power Development Authority (WAPDA). Both firms are engaged in three main activities such as power generation, distribution and transmission. For regulation National Electric Power Regulatory Authority (NEPRA) has been playing an important role. Since 2005 in Pakistan serious electricity crisis are experienced due to peak demand from both domestic consumption and industrial consumption. Economic Survey of Pakistan (2008) clearly indicated that in order to meet current demand concerned authorities must have to enhance generation capacity by $50 \%$. The surplus/deficit in demand and supply of electricity during peak hour actual figures of National Transmission \& Dispatch Company (NTDC) and K-Electric's are given below in tables.

Table \# 01

Surplus/Deficit in demand and Supply during Peak Hours (NTDC's system)

\begin{tabular}{|c|c|c|c|}
\hline Financial year ending 30 ${ }^{\text {th }}$ June & Generation capacity (MW) & Demand (MW) & Surplus/Deficit \\
\hline 2006 & 13,051 & 13,212 & -161 \\
\hline 2007 & 13,292 & 15,138 & $-1,846$ \\
\hline 2008 & 12,442 & 16,838 & $-4,396$ \\
\hline 2009 & 13,637 & 17,852 & $-4,215$ \\
\hline 2010 & 12,751 & 18,467 & $-5,716$ \\
\hline 2011 & 13,193 & 18,521 & $-5,328$ \\
\hline 2012 & 12,320 & 18,940 & $-6,620$ \\
\hline 2013 & 14,600 & 18,827 & $-4,227$ \\
\hline 2014 & 16,170 & 20,576 & $-4,406$ \\
\hline 2015 & 16,500 & 21,701 & $-5,201$ \\
\hline 2016 & 17,261 & 22,559 & $-5,298$ \\
\hline
\end{tabular}

Source: Various State of Industry Reports 2010, 2011 \& 2016 (NEPRA)

In the above table \# 1, we can see there is deficit of electricity from 2006 to 2016 and National Transmission \& Dispatch Company (NTDC) is unable to supply required electricity during peak demand. Continuous deficit is shown in the above table \#01, maximum shortfall was observed in $2012-6,620$ and average shortfall is $-4,310$. 
INTERNATIONAL JOURNAL OF ACADEMIC RESEARCH IN BUSINESS AND SOCIAL SCIENCES Vol. 8, No. 9, Sept. 2018, E-ISSN: 2222-6990 ㄷ 2018 HRMARS

Table\# 02

Surplus/Deficit in demand and Supply during Peak Hours (K-Electric's system)

\begin{tabular}{|c|c|c|c|}
\hline Financial year ending 30th June & Generation capacity (MW) & Demand (MW) & Surplus/Deficit \\
\hline 2006 & 2,117 & 2,223 & -106 \\
\hline 2007 & 2,283 & 2,349 & -66 \\
\hline 2008 & 2,265 & 2,443 & -178 \\
\hline 2009 & 2,403 & 2,462 & -59 \\
\hline 2010 & 2,393 & 2,562 & -169 \\
\hline 2011 & 2,237 & 2,565 & -328 \\
\hline 2012 & 2,163 & 2,596 & -433 \\
\hline 2013 & 2,246 & 2,778 & -532 \\
\hline 2014 & 2,601 & 2,929 & -328 \\
\hline 2015 & 2,632 & 3,056 & -424 \\
\hline
\end{tabular}

Source: Various State of Industry Report 2010, 2011 \& 2016 (NEPRA)

Similarly, in the above table \#02, we can see again there is deficit during peak hours and K-electric could not meet demand. Highest deficit is in $2013-532$ and average shortfall is -238 .

Graph \# 01

Source: Pakistan Economic survey 2015-16.

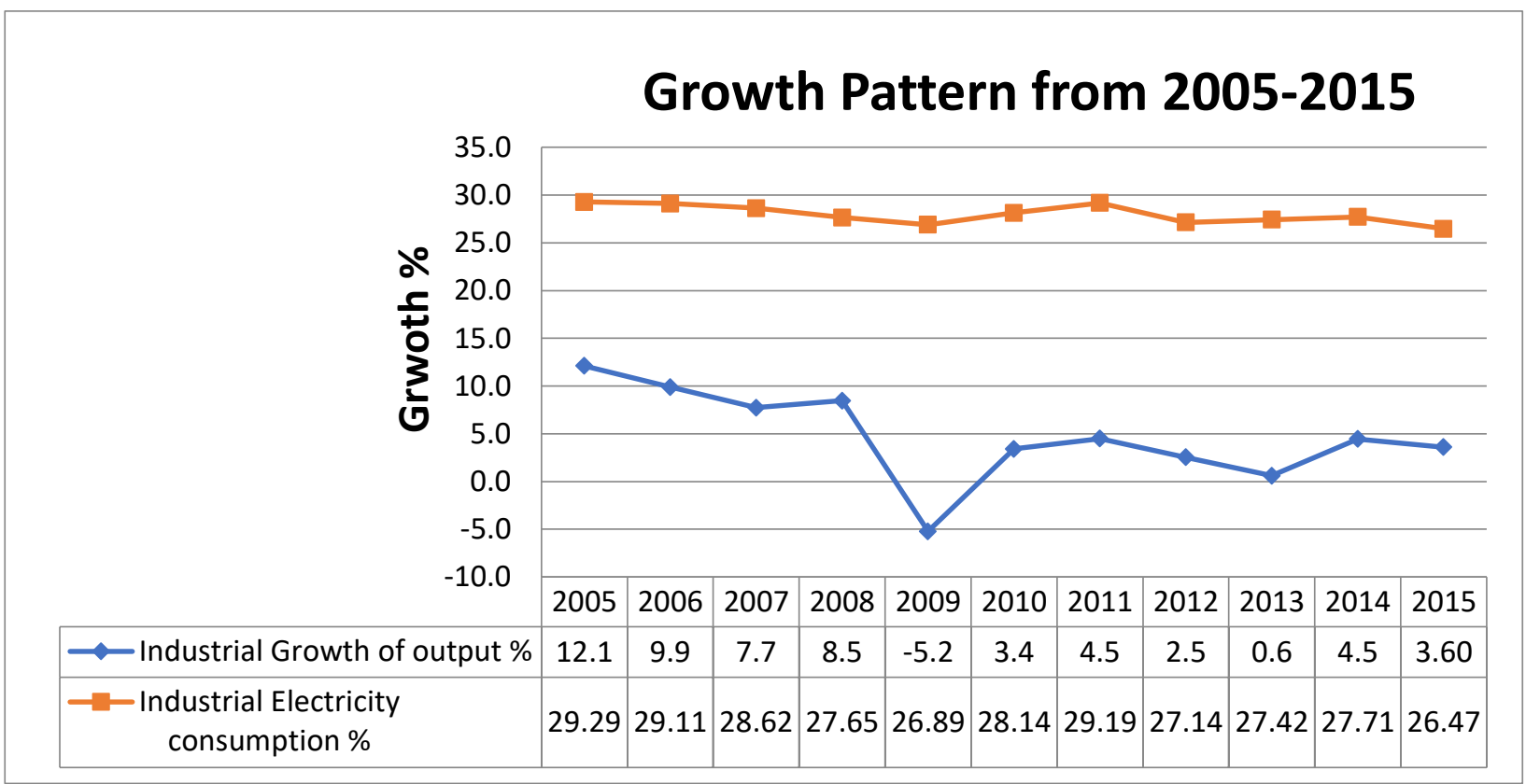

There is positive and direct relationship can be seen in above graph \#01 between industrial growth output percentage and industrial electricity consumption percentage. However, in 2013 industrial growth did not response with respect to industrial electricity consumption. Main reason can be 
INTERNATIONAL JOURNAL OF ACADEMIC RESEARCH IN BUSINESS AND SOCIAL SCIENCES Vol. 8, No. 9, Sept. 2018, E-ISSN: 2222-6990 @ 2018 HRMARS

election transitions of power from June-2012 to July 2013. In this time period usually economic activities remain inactive and investor confidence in terms of investment also decline due high risk factor.

Furthermore, according to Economic Survey of Pakistan (2016) in fiscal year 2016-17 the target of electricity and gas generation was $12.5 \%$, end up with $3.5 \%$ only. This reflects a huge gap in projected target and actual performance. Ultimately it will impact on output and industrial growth.

\section{Industrial Growth in Pakistan}

Industrial sector is $2^{\text {nd }}$ largest sector of Pakistan's economy in terms of growth. It supports directly and indirectly to two other main sectors of economy agriculture and service sector. In Last three years the industrial sector's performance can be appreciated, it indicates that a positive sustained growth of this sector.

Industrial sector helps government to generate revenue in form of taxes and create better job opportunities into economy in both aspects rural and urban workforce. This sector consists of manufacturing, mining and construction sub-sectors.

According to Minstery of Finance (2017) in the month of March-July 2017 large scale manufacturing (LSM) growth is 5.1 as compare 4.6 in 2016. The sectorial performance of Agriculture, Industrial and Service is given below graph \#02.

Graph \# 02

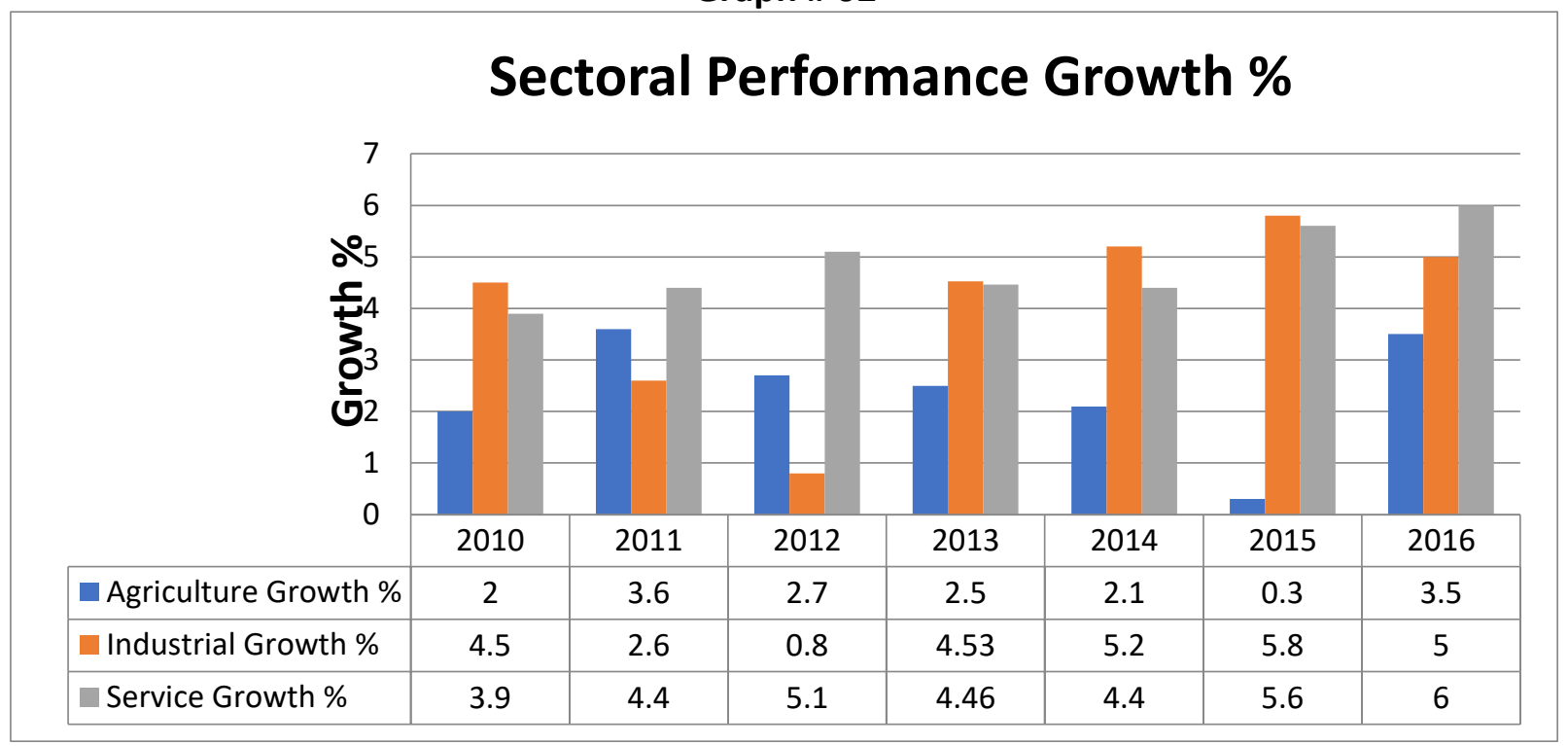

\section{Source: Pakistan Economic Survey 2016-17}

We can see in the graph \# 02, industrial sector growth cannot be underestimated especially in year 2010, 2013, 2014 and 2015. This performance can be further enhanced if; electricity crisis is addressed with effective planning in the future.

Fiscal year 2016-17 industrial sector had target of 7.7\% but ended being about $5.0 \%$. According to Economic Survey of Pakistan (2017) is due to energy crisis especially electricity and gas shortage to industries badly impact on overall all production level of industries. Similarly, large scale manufacturing sector also couldn't achieve target of 5.9\%, and LSM accomplished only $4.9 \%$. 


\section{Problem Statement}

Pervious scholars conducted on this related problem. Kiran (2016) conducted research on Pakistan's textile Industry and electricity crisis, the insufficient supply of electricity can negatively impact the export level. Pakistan has been facing serious problems in regard of electricity shortage, if this serious problem is not resolved than significant negative impact on overall economic growth of Pakistan (Kotani, 2014). Economic growth and energy crisis a strong correlation between GDP and energy consumption has been identified in this, due to shortage of electricity supply Pakistan is unable to achieve desired GDP growth from last one-decade (Khan, 2015).

\section{Research Gap}

There are two research gaps has been filled through this study. First, in past research scholar explored the problem of electricity overall on economic growth, GDP and related to specific industry such as textile (Kotani, 2014), (Kiran, 2016) \& (Khan, 2015). In this study we have emphasized the overall industrial sector that consists various industry such as manufacturing and construction so on. Second, in previous studies secondary data till 2010 has been analyzed for the conclusion their studies such as (Kotani, 2014) \& (Khan, 2015). In this study secondary data from 2005 to 2015 has been considered according to study objectives.

\section{Motivation of Study}

The electricity is considered an important as an input for industrial sector, due to shortage the factors would be able to produce anything. There are good number of companies are shifted to nearby countries from Pakistan because of this serious problem. Pakistan has been facing serious problem electricity shortage since 2005, this analysis will help to policy makers for developing and implementing polices. In today's discussion for economic perspective the energy crisis are main point of discussion among economist and researchers, this enforce us to verify the impact of electricity crisis on industrial growth in context of Pakistan.

\section{Research Objectives}

The following were the objectives of research:

I. To identify industrial annual growth rate of electricity consumption impact on industrial growth output percentage in Pakistan.

II. To analyze industrial consumer percentage impact on industrial growth output percentage in Pakistan.

III. To find industrial electricity consumption percentage impact on industrial growth output percentage in Pakistan.

IV. To identify electricity Industrial electricity consumption Gwh impact on industrial growth output percentage in Pakistan.

\section{Research Hypothesis}

The following were null research hypothesis guided the research:

$\mathrm{H}_{\mathbf{0}}$ 1: There is no significant impact of industrial annual growth rate of electricity consumption on industrial growth output percentage in Pakistan. 
INTERNATIONAL JOURNAL OF ACADEMIC RESEARCH IN BUSINESS AND SOCIAL SCIENCES

Vol. 8, No. 9, Sept. 2018, E-ISSN: 2222-6990 @ 2018 HRMARS

$\mathbf{H}_{0}$ 2: There is no significant impact of industrial consumer percentage on industrial growth output percentage in Pakistan.

$\mathbf{H}_{03}$ : There is no significant impact of electricity consumption percentage on industrial growth output percentage in Pakistan.

$\mathbf{H}_{0} 4$ : There is no significant impact of Industrial electricity consumption Gwh on industrial growth output percentage in Pakistan.

\section{Literature Review}

Nwankwo (2013) the impact of electricity supply on industrial production in Nigeria. In this study electricity supply, industrial production, gross fixed capital formation and population variables are studied. Secondary data from 1970 to 2010 are used and for the analysis of data the multiple regression analysis was applied. Based on multiple regression analysis results, a positive and significant relationship among industrial production, electricity supply, gross fixed capital formation and population were identified.

Kiran (2016) impact of electricity crisis on Pakistan textile industry. Primary and secondary data has been used for analysis. 150 questionnaires were distributed among textile industry working employees in various textile companies. The finding of this study revealed that there is significant impact of electricity crisis on production level, wages, employment opportunities and textile export level. It is highly recommended that these issues can be addressed if, the supply of energy ensured in future from concerned authorities.

Kotani (2014) an empirical analysis of electricity shortage in Pakistan. Time series data from 1971 to 2010 were used for examination of electricity shortage. The results of this study are concluded that price adjusted strategy adopted by Government of Pakistan is unable to bring acceptable results in short run and problem of electricity shortage can be addressed if, private electricity generation option utilized in effective manner. Electricity shortage eventually impacts on economic growth of Pakistan.

Osobase (2014) the relationship between electricity generation, supply and manufacturing sector performance in Nigeria. This study is based secondary data from 1975 to 2011. Government capital expenditure, inflation rate, exchange rate, capacity utilization, electricity generation and index of manufacturing production variables are studied. Correlation and Johnson co-integration techniques are used for analysis of data. Results indicated that there is positive relationship between index of manufacturing production and electricity generation and unidirectional relationship between electricity generation and index of manufacturing production.

Imoro Brainmah (2012) impact of unannounced electricity blackouts on operation of micro and small scale industries in Ghana. Sample size of 320 was selected from industrial cluster. Findings of this research revealed that an average of 10.3 hours' blackout was estimated in per month. Due to lack of an alternative of electricity firms face huge cost of production and maintained same labor cost. This study concluded that uninterrupted electricity supply effect on operation of micro and small scale industries.

Mayo (2012) power cuts impact on productivity: a case study of Nigeria manufacturing firms. OLS and Tobit model statistical techniques were used. Power outage variable has negative and significant 
impact on productivity in Nigeria. Based on results, it is suggested that Nigeria Government should improve electricity generation and supply for better productivity in future.

Khan (2015) impact of energy crisis on economic growth of Pakistan. Sample data from 1982 to 2010 has been analyzed in this study. Correlation and liner regression analysis techniques are used for the conclusion of study. Based on correlation results, there is strong relationship between GDP and energy consumption. Government of Pakistan should take corrective actions for energy generation through various alternatives for sake of better economic growth in Pakistan.

Kaseke (2013) emergence of electricity crisis in Zimbabwe, reform analysis and cost implication. A finding of this study suggested that generation of electricity is problem in Zimbabwe due to old equipment, lack of spares and maintenance. Tariff reform unable to settle this power outage and demand in household badly impact on industrial electricity consumption. This had ultimately an impact on direct and indirect costs, which experienced an increase. Policy makers and concerned officials should take corrective actions for better economic growth in Zimbabwe.

\section{Method and Model Specification}

\section{Data Source}

This research is based on secondary data and we have collected the data through Asian Development Bank, Power System Statistics and National Electric Power Regulatory Authority (NEPRA). All data sets used in this study are from 2005 to 2015. 
INTERNATIONAL JOURNAL OF ACADEMIC RESEARCH IN BUSINESS AND SOCIAL SCIENCES Vol. 8, No. 9, Sept. 2018, E-ISSN: 2222-6990 @ 2018 HRMARS

Table\# 03

\begin{tabular}{|c|c|c|c|c|c|}
\hline Year & $\begin{array}{l}\text { Industrial } \\
\text { Growth of } \\
\text { output \% }\end{array}$ & $\begin{array}{l}\text { Industrial annual } \\
\text { growth rate } \\
\text { of electricity } \\
\text { consumption \% }\end{array}$ & $\begin{array}{c}\text { Industrial } \\
\text { consumers } \\
\%\end{array}$ & $\begin{array}{c}\text { Industrial } \\
\text { Electricity } \\
\text { consumption \% }\end{array}$ & $\begin{array}{l}\text { Industrial Electricity } \\
\text { consumption (Gwh) }\end{array}$ \\
\hline $005^{2}$ & 12.1 & 6.23 & 1.37 & 29.29 & 19,799 \\
\hline $006^{2}$ & 9.9 & 5.90 & 1.35 & 29.11 & 20,968 \\
\hline $\begin{array}{c}{ }^{2} \\
007\end{array}$ & 7.7 & -0.66 & 1.32 & 28.62 & 20,829 \\
\hline $\begin{array}{c}{ }^{2} \\
008\end{array}$ & 8.5 & -7.52 & 1.32 & 27.65 & 19,262 \\
\hline $\begin{array}{c}{ }^{2} \\
009\end{array}$ & -5.2 & 2.69 & 1.31 & 26.89 & 19,781 \\
\hline $010^{2}$ & 3.4 & 4.98 & 1.31 & 28.14 & 20,766 \\
\hline $011^{2}$ & 4.5 & 2.73 & 1.32 & 29.19 & 21,334 \\
\hline $012^{2}$ & 2.5 & 1.59 & 1.32 & 27.14 & 22,086 \\
\hline $013^{2}$ & 0.6 & 9.20 & 1.32 & 27.42 & 24,118 \\
\hline $014^{2}$ & 4.5 & 3.31 & 1.31 & 27.71 & 24,917 \\
\hline $015^{2}$ & 3.60 & 0.24 & 1.30 & 26.47 & 24,977 \\
\hline
\end{tabular}

Source: Various State of Industry Report (NEPRA) \& Asian Development Bank.

\section{Research Model}

$$
I G O P=\alpha 0+\beta_{1} I E C P+\beta_{2} I C P+\beta_{3} I E C G+\beta_{4} I A G R C+\text { eit }
$$

Whereas, Industrial growth output percentage (IGOP), Industrial electricity consumption percentage (IECP), Industrial consumer percentage (ICP), Industrial electricity consumption Gwh (IECG), Industrial annual growth rate consumption (IAGRC) and error (eit)

\section{Multiple Regression Analysis}

The multiple regression analysis technique used to apply for measuring the relationship between dependent variable and more than one independent variable. In this study there are four independent variables industrial electricity consumption percentage, industrial consumer percentage, industrial electricity consumption Gwh, industrial annual growth rate consumption and one dependent variable industrial growth output percentage. 
INTERNATIONAL JOURNAL OF ACADEMIC RESEARCH IN BUSINESS AND SOCIAL SCIENCES

Vol. 8, No. 9, Sept. 2018, E-ISSN: 2222-6990 (C) 2018 HRMARS

Results and Discussion

Multiple Regression Analysis

Table \# 04

Model summary

\begin{tabular}{|l|c|c|}
\hline \multicolumn{1}{|c|}{ Variable } & R value & $\begin{array}{c}\text { Adjusted R square } \\
\text { value }\end{array}$ \\
\cline { 1 - 1 } Industrial Growth of output \% (Dependent) & \\
\cline { 1 - 1 } $\begin{array}{l}\text { Industrial annual growth rate of electricity } \\
\text { consumption \% (Independent) }\end{array}$ & \multirow{2}{*}{88.4} & 80.6 \\
\cline { 1 - 1 } Industrial consumers \% (Independent) & \\
\cline { 1 - 1 } Industrial Electricity consumption \% (Independent) & & \\
\cline { 1 - 2 } $\begin{array}{l}\text { Industrial Electricity consumption (Gwh) } \\
\text { (Independent) }\end{array}$ & & \\
\hline
\end{tabular}

\section{Source: Author's estimation}

In table \#04, model summery indicates the relationship between estimated value of dependent variable and studied variables. All mentioned independent variables shows the $R$ value is in this study $88.4 \%$ and adjusted $R$ value also indicates overall fitness of model $80.6 \%$.

\section{ANOVA}

Table \# 05

ANOVA

\begin{tabular}{|c|c|}
\hline Variable & p-value \\
\hline Industrial Growth of output \% (Dependent) & \multirow{5}{*}{.006} \\
\hline $\begin{array}{l}\text { Industrial annual growth rate of electricity } \\
\text { consumption \% (Independent) }\end{array}$ & \\
\hline Industrial consumers \% (Independent) & \\
\hline Industrial Electricity consumption \% (Independent) & \\
\hline Industrial Electricity consumption (Gwh) & \\
\hline
\end{tabular}

Source: Author's estimation

Table \# 05 indicates fitness of model, in our case the value of $p$ is 0.006 which is less than 0.05 . This $\mathrm{p}$-value concludes our studied research model is fit and we can predict the results of dependent variables with respect to independent variables. 
INTERNATIONAL JOURNAL OF ACADEMIC RESEARCH IN BUSINESS AND SOCIAL SCIENCES

Vol. 8, No. 9, Sept. 2018, E-ISSN: 2222-6990 @ 2018 HRMARS

\section{Coefficient}

Table \# 06

Coefficient

\begin{tabular}{|l|c|c|l|}
\hline \multicolumn{1}{|c|}{$\begin{array}{c}\text { Variables } \\
\text { (Independent) }\end{array}$} & Beta value & p-value & $\begin{array}{l}\text { Decision rule p value } \\
\text { less than } \mathbf{0 . 0 5}\end{array}$ \\
\hline $\begin{array}{l}\text { Industrial annual growth rate of } \\
\text { electricity consumption \% }\end{array}$ & .698 & 0.007 & Significant \\
\hline Industrial consumers \% & .766 & 0.014 & Significant \\
\hline $\begin{array}{l}\text { Industrial Electricity } \\
\text { consumption \% }\end{array}$ & .559 & 0.036 & Significant \\
\hline $\begin{array}{l}\text { Industrial Electricity } \\
\text { consumption (Gwh) }\end{array}$ & .547 & 0.027 & Significant \\
\hline
\end{tabular}

\section{Dependent variable: Industrial Growth of output \%}

\section{Source: Author's estimations}

Industrial growth of output $\%=-338.333+.698$ Industrial annual growth rate of electricity consumption $\%+(.766)$ Industrial consumers $\%+(.559)$ Industrial electricity consumption $\%+(.547)$ Industrial electricity consumption (Gwh).

A coefficient table shows two important values, value of beta and $p$-value. The value of beta usually determines the relationship between dependent variable with independent variables whereas $p$ value shows level of significance. We can see in this study all studied variables industrial annual growth rate of electricity consumption \%, industrial consumer \%, Industrial electricity consumption $\%$ and industrial electricity consumption (Gwh) are found to have positive and significant relationship with dependent variable Industrial growth of output \%.

\section{Conclusion and Recommendations \\ Conclusion}

The main purpose of this study was to find the impact of electricity crisis on industrial growth of output percentage in Pakistan. Secondary data has been analyzed from 2005-2015 in SPSS version 17 through multiple regression analysis technique. The electricity serves main source of input for industries but since 2005 great fluctuations have been observed in Pakistan.

Results of this study indicated that all studied variables in this study annual growth rate of electricity consumption \%, industrial consumer \%, Industrial electricity consumption \% and industrial electricity consumption (Gwh) have positive and significant impact on industrial growth of output \%. On basis of results we can concluded that industrial growth of output can be badly affected due to electricity fluctuations of demand and supply in Pakistan. In order to address this problem following recommendation are suggested based on results of this study.

\section{Recommendations}

- Solar energy and Hydro energy resources can be used in order to the address the energy issues for industrial growth in Pakistan.

- The industrial development in Pakistan and electricity production should be priorities in the annual budget scheme. 
INTERNATIONAL JOURNAL OF ACADEMIC RESEARCH IN BUSINESS AND SOCIAL SCIENCES

Vol. 8, No. 9, Sept. 2018, E-ISSN: 2222-6990 @ 2018 HRMARS

- Both the domestic investors and international investors should be encouraged to make investment into power generation in the Pakistan through support of government level.

\section{Future Research Recommendations.}

- This study can be extended to other developing countries like Bangladesh, India and South African countries.

- A comparative analysis can be performed between Pakistan's nearby countries such Bangladesh and India.

- Pakistan other sectors are also affected due to electricity crisis, impact of electricity crisis can be analyzed on service sector and agriculture sectors.

\section{References}

Bank, World. (2005). World development report. Washtgan DC: World Bank.

Finance, M. O. (2016). Pakistan Economic Survey. Islamabad: Minstery of Finance.

Finance, Minstery of. (2008). Pakistan Economic Survey. Islamabad: Minstery of Finance.

Imoro Braimah, O. A. (2012). Causes and Effects of Frequent and Unannounced Electricity Blackouts on the Operations of Micro and Small Scale Industries in Kumasi. Journal of Sustainable Development, 17-36.

Kaseke, N. (2013). Emergence Of Electricity Crisis In Zimbabwe, Reform Response And Cost Implications. Journal of Business Management \& Social Sciences Research, 1-16.

Khan, D. I. (2015). Impact of Energy Crisis on Economic Growth of Pakistan. International Journal of African and Asian Studies, 33-42.

Kiran, D. A. (2016). Impact of electrcity crisis on Pakistan textile Industry. Internationl Journal of Economic and Business Review, 15-23.

Kotani, M. Q. (2014). AN EMPIRICAL ANALYSIS OF ENERGY SHORTAGE IN PAKISTAN. Asia-Pacific Development Journal, 137-166.

Minstery of Finance. (2017). Pakistan Economic Survey. Islamabad: Minstery of Finance.

Moyo, B. (2012). Do Power Cuts Affect Productivity? A Case Study Of Nigerian Manufacturing Firms. International Business \& Economics Research Journal, 1163-1173.

MRS NWANKWO, O. C. (2013). The Effect of Electricity Supply on Industrial Production Within The Nigerian Economy (1970 - 2010). Journal of Energy Technologies and Policy, 34-42.

NEPRA. (2016). State of industry report. Islamabad: NEPRA.

Osobase, A. O.-A. (2014). The nexus between electricity generation, supply and manufacturing sector performance in Nigeria (1975-2011). International Journal of Management Sciences and Humanities, 184-207. 